\title{
Pengaruh Auditor Judgement, Etika Profesi, dan Employee Engagement terhadap Kinerja Auditor dalam Pelaksanaan Pemeriksaan Laporan Keuangan (Studi pada Badan Pemeriksa Keuangan RI)
}

\author{
Nissa Hanny Tatiara ${ }^{(1)}$, Citra Sukmadilaga ${ }^{(2)}$, Ida Farida ${ }^{(3)}$ \\ Program Studi Magister Akuntansi Universitas Padjadjaran Bandung \\ Jalan Japati No. 4. Telp (022) 2535172 Bandung 40133 \\ e-mail: nissa.tatiara@bpk.go.id
}

\begin{abstract}
ABSTRAK
Dalam melaksanakan pemeriksaan laporan keuangan, kinerja auditor yang baik menjadi kunci utama suksesnya hasil pemeriksaan laporan keuangan tersebut. Beberapa kemungkinan penyebab kelemahan kinerja auditor karena masih terdapat auditor yang bisa dipengaruhi dalam pembuatan auditor judgement, terdapat kelemahan auditor dalam menerapkan prinsip etika profesi, dan lemahnya keterikatan pribadi auditor tersebut dengan pemberi kerjanya. Studi ini dilakukan pada Badan Pemeriksa Keuangan RI. Riset ini bertujuan untuk mengatahui seberapa besar auditor judgement, penerapan etika profesi, dan employee engagement seorang auditor berpengaruh terhadap kinerja auditor tersebut. Data dikumpulkan menggunakan metode survei dengan teknik kuesioner. Jumlah responden penelitian ini adalah 86 responden, namun data responden yang dapat diolah adalah 84 kuesioner. Teknik analisis data yang digunakan adalah regresi linier berganda. Hasil penelitian menunjukkan bahwa auditor judgement, etika profesi, dan employee engagement secara parsial dan bersama-sama (simultan) berpengaruh signifikan terhadap kinerja auditor.
\end{abstract}

Kata kunci : auditor judgement, etika profesi, employee engagement, kinerja auditor

\begin{abstract}
In financial statement audits, a good auditor's performance is the main key to the success of the results of auditing the financial statements. Some possible causes of auditor performance weakness are because there are still auditors who can be influenced in making auditor judgment, there are weaknesses of auditors in applying the principles of professional ethics, and the auditor's personal attachment to his employer. This study was conducted at the Indonesian Supreme Audit Board. This research aims to find out how much auditor judgment, the application of professional ethics, and employee engagement of an auditor influences the auditor's performance. Data were collected using a survey method with a questionnaire technique. The number of respondents in this study is 86 respondents, but respondent data that can be processed is 84 questionnaires. The data analysis technique used is multiple linear regression. The results showed that auditor judgment, professional ethics, and employee engagement partially and simultaneously had a significant effect on auditor performance.
\end{abstract}

Keywords : auditor judgement, professional ethics, employee engagement, auditor performance

\section{PENDAHULUAN}

Sebagai salah satu lembaga negara yang dibentuk dan diatur di dalam UUD 1945, Badan Pemeriksa Keuangan (BPK) dan lembaga negara lain memiliki tugas untuk mendorong pencapaian tujuan negara. Hal ini dilakukan BPK melalui pemeriksaan pengelolaan dan tanggung jawab keuangan negara secara bebas dan mandiri. Dalam melaksanaan tugas pemeriksaan, standar pemeriksaan yang digunakan BPK adalah Standar Pemeriksaan Keuangan Negara (SPKN). Dalam SPKN dijelaskan jenis pemeriksaan keuangan negara meliputi pemeriksa- an keuangan, kinerja, dan dengan tujuan tertentu (PDTT). Hasil pemeriksan keuangan oleh BPK yaitu opini pemeriksaan berupa penyajian laporan keuangan yang Wajar Tanpa Pengecualian (WTP), Wajar Dengan Pengecualian (WDP), Tidak Memberikan Pendapat (TMP), dan Tidak Wajar (TW).

Hasil pemeriksaan BPK atas pengelolaan keuangan negara/ daerah disampaikan kepada Presiden, DPR, DPD, dan DPRD sesuai dengan kewenangannya. Pada Semester I Tahun 2019, BPK telah menyerahkan hasil pemeriksaan pada Laporan 
pada Laporan Keuangan Pemerintah Pusat (LKPP) termasuk Kementerian/Lembaga (LKKL) TA 2018. Dari Laporan Hasil Pemeriksaan (LHP) atas LKPP dan LKKL TA 2018 menunjukkan sebanyak 82 LKKL-LK BUN memperoleh opini WTP dan 4 LKKL memperoleh opini WDP serta 1 LKKL yang memperoleh opini TMP. Hal ini menunjukkan peningkatan opini dari sejumlah entitas jika dibandingkan dengan Laporan Hasil Pemeriksaan (LHP) atas LKPP dan LKKL TA 2017 yaitu sebanyak 79 LKKL-LK BUN memperoleh opini WTP dan 6 LKKL memperoleh opini WDP serta 2 LKKL yang memperoleh opini TMP (Resume LHP atas LKPP dan LKKL TA 2017 dan 2018).

Dalam melaksanakan tugasnya memeriksa laporan keuangan, auditor judgement sangat dibutuhkan karena akan digunakan sebagai bahan pertimbangan untuk menentukan judgement akhir berupa pernyataan wajar atau tidak wajar atas laporan keuangan yang diperiksa, bahkan ketika auditor telah memberikan judgement sekalipun masih terdapat kemungkinan terjadinya kecurangan dalam laporan keuangan. Berdasarkan pengamatan dari laporan tahunan yang diterbitkan oleh Komisi Pemberantasan Korupsi (KPK) tahun 2018, kasus korupsi cenderung mengalami kenaikan dari tahun ke tahun. Sepanjang tahun 2017 perkara yang berkekuatan hukum tetap (inkracht) yaitu sejumlah 84 perkara. Jumlah tersebut mengalami kenaikan sepanjang tahun 2018 tercatat ada sejumlah 106 perkara. Ini menjadi tantangan besar bagi kinerja auditor BPK dalam melakukan pemeriksaan laporan keuangan, bagaimana auditor dapat mempertimbangkan faktor-faktor penting dalam penentuan program pemeriksaan yang tepat bagi entitas yang memiliki anggaran yang tinggi dan rawan terjadi korupsi.

Tahun 2017 BPK menghadapi tantangan yaitu kasus dugaan suap terkait dengan pemberian opini WTP terhadap laporan keuangan Kementerian Desa Pembangun Daerah Tertinggal dan Transmigrasi dan dugaan suap dari PT Jasa Marga terhadap auditor BPK. Media dengan cepat dan massive-nya menyampaikan informasi tersebut kepada masyarakat, mengakibatkan sedikit banyak mengganggu pandangan publik atas reputasi dan kredibiltas BPK RI.

Rincian kasus suap auditor BPK yang diproses KPK dan sudah berkuatan hukum tetap (inkracht) dari tahun 2008 s.d. 2019. Berdasarkan laporan yang ada dapat disimpulkan bahwa masih lemahnya penerapan kode etik BPK. Kasus-kasus tersebut tentu saja mengikis kepercayaan masyarakat terhadap BPK. Berdasarkan keterangan dari Biro SDM, Biro Humas dan Inspektorat Utama BPK diketahui terdapat peningkatan hukuman disiplin yang diterima pegawai dari tahun 2017 ke tahun 2018, masih terdapat beberapa pengaduan terhadap auditor BPK dan pelanggaran kode etik yang dilakukan auditor BPK.

Saat ini, BPK masih memiliki kendala yaitu kurangnya jumlah auditor, frekuensi dan intensitas tugas audit yang semakin meningkat serta terbatasnya waktu yang ada, mengakibatkan kelelahan yang dialami para auditor. BPK memberikan kesempatan bagi pegawai non pemeriksa untuk pindah status menjadi pemeriksa penuh. Hal ini dilakukan untuk mengimbangi jumlah pemeriksa yang keluar dari organisasi atau berpindah status menjadi pegawai non pemeriksa. Selain itu, juga disebabkan oleh tingginya kelelahan atas beban kerja yang dialami oleh pemeriksa. Kelelahan para pemeriksa ini dapat memunculkan sikap negatif terhadap pekerjaan, selanjutnya, hal ini mengurangi tingkat engagement dengan pekerjaan tersebut (Khairani, 2014). Turunnya tingkat employee engagement tersebut dapat mengindikasikan turunnya kinerja pemeriksa.

Dari fenomena yang terjadi menunjukan masih lemahnya kinerja auditor BPK. Beberapa kemungkinan penyebab terjadinya hal tersebut karena masih terdapat auditor yang bisa dipengaruhi dalam pembuatan auditor judgement, terdapat kelemahan auditor dalam menerapkan prinsip etika profesi, dan lemahnya keterikatan pribadi auditor tersebut dengan pemberi kerjanya (dalam hal ini BPK). Fenomena tersebut menimbulkan pertanyaan penelitian, dalam pemeriksaan laporan keuangan Seberapa besar pengaruh auditor judgement, penerapan etika profesi, dan employee engagement seorang auditor terhadap kinerja auditor tersebut?

\section{Pemeriksaan Laporan Keuangan}

Pemeriksaan ini laporan keuangan bertujuan untuk memberikan opini atas kewajaran laporan keuangan. Pihak stakeholder memiliki ekspeksi yang tinggi terhadap transparansi dan akuntabilitas pengelolaan keuangan negara baik dari sudut pandang kualitas laporan keuangan pemerintah pusat maupun daerah dan kualitas dari pemeriksaan yang dilakukan BPK.

Menurut Ghozali dan Chariri (2014) teori stakeholder perusahaan bukanlah entitas yang hanya beroperasi untuk kepentingan sendiri, namun harus memberikan manfaat kepada seluruh stakeholdernya. Oleh karena itu BPK tidak dapat melepaskan diri dari lingkungan sosial. BPK perlu menjaga legitimasi stakeholder serta mendudukkannya dalam kerangka kebijakan dan pengambilan 
keputusan, sehingga dapat mendukung pencapaian tujuan BPK.

\section{Kinerja Auditor}

Menurut Nugraha dan Ramantha (2015), kinerja auditor menjadi salah satu tolak ukur yang digunakan untuk menentukan apakah suatu pekerjaan yang dilakukan akan baik atau sebaliknya. Dalam teori penetapan tujuan, Edwin Locke (1990) membandingkan kinerja sesorang berdasarkan jelas atau tidaknya tujuan yang ingin dicapai, dimana orang yang memiliki tujuan yang jelas akan lebih baik kinerjanya dari pada orang miliki tujuan yang tidak jelas. Goal setting theory menyatakan bahwa orang yang memiliki sasaran yang spesifik dan menantang berkinerja lebih baik dibanding dengan orang yang tidak memiliki sasaran jelas. Penelitian ini menggunakan dimensi pengukuran kinerja yaitu: Effort, Job Knowledge, Quality, Quantity, Compliance with rules, dan Interpersonal competence.

\section{Auditor Judgement}

Dalam PSP Nomor 100 (SPKN, 2017) dinyatakan bahwa pemeriksa harus menggunakan pertimbangan profesional dalam membuat keputusan tentang risiko pemeriksaan. Auditor judgement sangat tergantung dari pemahaman mengenai suatu kondisi tertentu. Pengaplikasian teori kognitif dapat digunakan untuk mengkaji kemampuan yang dimiliki auditor dalam mengambil suatu pertimbangan audit. Hogart (1992) dalam Jamilah, dkk (2007) mengartikan judgement sebagai prosess kognitif yang merupakan perilaku pemilihan keputusan. Dua dimensi pertimbangan professional pemeriksa dalam penelitian ini berdasarkan SPKN dan Arens (2014) yaitu Pertimbangan risiko pemeriksaan dan Pertimbangan materialitas.

\section{Etika Profesi}

Etika profesi merupakan standar sikap para anggota profesi yang dirancang agar praktis dan realistis, tetapi seapat mungkin idealistis. Tuntutan etika profesi harus di atas hukum tetapi dibawah standar ideal (absolut) agar etika tersebut mempunyai arti dan berfungsi sebagai mana mestinya. Berdasarkan SPKN, salah satu faktor yang harus dimiliki seorang auditor BPK yaitu etika profesi. BPK telah merumuskan suatu kode etik yang harus dipedomani oleh seluruh anggota BPK dan pemeriksa. Dimensi penelitian ini berdasarkan Peraturan BPK RI No. 3 Tahun 2016 tentang Kode Etik BPK yaitu: Independensi, Integritas dan Profesionalisme yang menjadi nilai luhur BPK.

\section{Employee Engagement}

Dalam Rich (2010), Khan (1990) menyatakan bahwa engagement merupakan keadaan dimana anggota dari sebuah organisasi melaksanakan peran kerjanya, bekerja dan mengekspresikan dirinya secara fisik (energik), kognitif (keinginan yang dimiliki karyawan mengenai organisasi, pemimpin, dan kondisi kerja dalam organisasi) dan emosional (meliputi perasaan karyawan terhadap organisasi dan pemimpinnya selama menunjukkan kinerja mereka. Pengaplikasian teori akuntansi perilaku digunakan pada variabel etika profesi dan employee engagement. Siegel dan Marconi (1986) mengemukakan bahwa faktor-faktor psikologi dan sosial psikologi meliputi motivasi, persepsi, sikap dan personalitas sangat relevan dengan bidang akuntansi.

Berdasarkan paparan inilah yang membuat penting-nya dilakukan pengujian auditor judgement, etika yang baik dilihat dari kinerja. Semakin baik auditor judgement yang dibuat oleh auditor diharapkan semakin baik kualitas hasil audit. Sehingga, hipotesis dalam penelitian ini adalah

$\mathrm{H}_{1}=$ auditor judgement berpengaruh signifikan terhadap kinerja auditor dalam pelaksanaan pemeriksaan laporan keuangan.

$\mathrm{H}_{2}=$ etika profesi berpengaruh signifikan terhadap kinerja auditor dalam pelaksanaan pemeriksaan laporan keuangan.

$\mathrm{H}_{3}=$ employee engagement berpengaruh signifikan terhadap kinerja auditor dalam pelaksanaan pemeriksaan laporan keuangan.

$\mathrm{H}_{4}=$ auditor judgement, etika profesi, dan employee engagement secara bersama-sama berpengaruh signifikan terhadap kinerja auditor dalam pelaksanaan pemeriksaan laporan keuangan

\section{METODE PENELITIAN}

Metode penelitian yang digunakan adalah explanatory research. Penelitian ini dilakukan untuk memperoleh deskripsi atau gambaran secara sistematis faktual dan akurat mengenai fakta-fakta, sifat-sifat serta hubungan antar variable yang diteliti (Bougie dan Sekaran, 2013).

Dalam penelitian ini terdapat empat variabel yang akan diteliti yaitu:

a. Auditor judgement sebagai variable independen (X1);

b. Etika profesi sebagai variabel independen (X2);

c. Employee engagement sebagai variabel independen (X3); 
J Statistika Vol. 12, No. 2, (2019), Hal. 1-8

d. Kinerja auditor sebagai variabel dependen (Y).

Penelitian ini menggunakan data primer dengan teknik pengumpulan data yang dilakukan dengan metode angket/kuesioner dan didukung dengan interview/wawancara.

Variabel independen dan dependen pada penelitian ini diukur dengan instrument pengukur dalam bentuk kuesioner berskala ordinal yang memenuhi pernyataan-pernyataan skala likert. Skor atas pilihan jawaban untuk kuesioner yang diajukan untuk pernyataan adalah skala 1,2,3,4 dan 5 dengan bobot tertinggi adalah 5 dan bobot terendah adalah 1 (Sugiyono, 2016).

Dalam penelitian ini yang menjadi populasi adalah seluruh auditor yang bertugas melakukan pemeriksaan Laporan Keuangan Kementerian dan Lembaga (LKKL) atau Laporan Keuangan Pemerintah Pusat (LKPP) serta Laporan Keuangan Pemerintah Daerah (LKPD) Tahun Anggaran 2018.

Pemilihan sampel pada penelitian ini dengan pertimbangan kriteria yaitu Ketua Tim yang memimpin pemeriksaan atas LKKL/LKPP TA 2018 karena terkait dengan pemeriksaan atas pengelolaan APBN. Dengan demikian, sampel penelitian ini berjumlah 86 Ketua Tim pada Pemeriksaan LKKL/LKPP TA 2018.

Analisis yang digunakan dalam penelitian ini yaitu analisis regresi linier berganda. Adapun persamaannya sebagai berikut:

$$
Y=\alpha+\beta_{1} \cdot X_{1}+\beta_{2} \cdot X_{2}+\beta_{3} \cdot X_{3}+\varepsilon
$$

Keterangan:

Y : Kinerja Auditor

$\alpha \quad$ : Konstanta

$\beta \quad$ : Koefisien regresi

$\mathrm{X}_{1} \quad$ : Variabel auditor judgement

$\mathrm{X}_{2} \quad$ : Variabel etika profesi

$\mathrm{X}_{3} \quad$ : Variabel employee enggagement

$\varepsilon \quad:$ error

\section{HASIL DAN PEMBAHASAN}

\subsection{Analisa Deskriptif}

Pada analisis deskriptif ini, data responden dijelaskan melalui Tabel 1. Selanjutnya pemusatan data, ukuran letak, dan keragaman data disajikan dalam Tabel 2. Pata Tabel 2 dapat diketahui nilai maksimum, minimum, nilai rata-rata, median dan standart deviasi dari variabel auditor judgement, etika profesi, employee engagement, dan kinerja auditor. www.unipasby.ac.id

Tabel 1. Gambaran Identitas Responden

\begin{tabular}{|c|c|c|}
\hline \multicolumn{3}{|c|}{ Identitas Responden } \\
\hline Peran/Jabatan & Frekuensi & Persentase \\
\hline Ketua Tim & 84 & $100.00 \%$ \\
\hline Jumlah & 84 & $100.00 \%$ \\
\hline \multicolumn{3}{|l|}{ Gender } \\
\hline Laki-laki & 58 & $69.05 \%$ \\
\hline Perempuan & 26 & $30.95 \%$ \\
\hline Jumlah & 84 & $100.00 \%$ \\
\hline \multicolumn{3}{|l|}{ Satker } \\
\hline AKN I & 23 & $27.38 \%$ \\
\hline AKN II & 11 & $13.10 \%$ \\
\hline AKN III & 34 & $40.48 \%$ \\
\hline AKN IV & 6 & $7.14 \%$ \\
\hline AKN V & 6 & $7.14 \%$ \\
\hline AKN VI & 3 & $3.57 \%$ \\
\hline AKN VII & 1 & $1.19 \%$ \\
\hline Jumlah & 84 & $100.00 \%$ \\
\hline
\end{tabular}

Tabel 2. Ukuran Pemusatan dan Keragaman Data

\begin{tabular}{|c|c|c|c|c|c|c|}
\hline Variabel & Dimensi & Max & Min & Mean & Med & S.Dev \\
\hline \multirow{2}{*}{$\begin{array}{l}\text { Auditor } \\
\text { Judgement }\end{array}$} & $\begin{array}{l}\text { Pertimbangan } \\
\text { Risiko } \\
\text { Pemeriksaan }\end{array}$ & 30 & 7 & 3.9 & 4 & 0.08 \\
\hline & $\begin{array}{l}\text { Pertimbangan } \\
\text { Materialitas }\end{array}$ & 25 & 7 & 3.87 & 4 & 0.05 \\
\hline \multirow{3}{*}{$\begin{array}{l}\text { Etika } \\
\text { Profesi }\end{array}$} & Independensi & 15 & 5 & 3.73 & 4 & 0.08 \\
\hline & Integritas & 20 & 6 & 3.89 & 4 & 0.11 \\
\hline & Profesionalisme & 25 & 6 & 3.71 & 4 & 0.07 \\
\hline \multirow{3}{*}{$\begin{array}{l}\text { Employee } \\
\text { Engagement }\end{array}$} & Vigor & 10 & 2 & 4.02 & 4 & 0.09 \\
\hline & Dedication & 20 & 5 & 3.99 & 4 & 0.06 \\
\hline & Absobtion & 15 & 4 & 4.17 & 4 & 0.06 \\
\hline \multirow{6}{*}{$\begin{array}{l}\text { Kinerja } \\
\text { Auditor }\end{array}$} & Effort & 10 & 3 & 3.65 & 4 & 0.03 \\
\hline & Job Knowledge & 19 & 7 & 3.9 & 4 & 0.04 \\
\hline & Quality & 15 & 3 & 4.09 & 4 & 0.04 \\
\hline & Quantity & 19 & 5 & 3.73 & 4 & 0.02 \\
\hline & $\begin{array}{l}\text { Compliance } \\
\text { with Rules }\end{array}$ & 15 & 3 & 3.92 & 4 & 0.00 \\
\hline & $\begin{array}{l}\text { Interpersonal } \\
\text { competence }\end{array}$ & 10 & 2 & 3.89 & 4 & 0.04 \\
\hline
\end{tabular}

\subsection{Uji Asumsi Klasik}

1. Uji Normalitas

Pengujian normalitas data dalam penelitian ini menggunakan Kolmogorov-Smirnovs. Hasil pengujian normalitas data dapat dilihat pada Tabel 3 sebagai berikut: 
Tabel 3. Pengujian Kolmogorov-Smirnovs

\begin{tabular}{|l|l|r|}
\hline \multicolumn{2}{|l|}{} & \multicolumn{1}{|c|}{$\begin{array}{c}\text { Kinerja } \\
\text { Auditor (Y) }\end{array}$} \\
\hline N & Mean \\
\hline $\begin{array}{l}\text { Normal } \\
\text { Parameters }\end{array}$ & Std. Deviation & 60,934 \\
\hline Most Extreme & Absolute & 10,523 \\
\hline \multirow{2}{*}{ Differences } & Positive & 0,142 \\
\cline { 2 - 3 } & Negative & 0,072 \\
\hline $\begin{array}{l}\text { Kolmogorov- } \\
\text { Smirnov Z }\end{array}$ & & $-0,142$ \\
\hline $\begin{array}{l}\text { Asymp. Sig. } \\
\text { (2-tailed) }\end{array}$ & & 1,301 \\
\hline
\end{tabular}

Berdasarkan output SPSS di atas diperoleh nilai Sig. uji normalitas dengan menggunakan metode Kolmogorov-Smirnovs sebesar 0,068. Dikarenakan nilai $p$-value tersebut lebih besar dari alpha $(0,068>$ 0,05), maka dapat disimpulkan bahwa residual data berdistribusi normal.

\section{Uji Heteroskedastisitas}

Uji Heteroskedastisitas dalam penelitian ini menggunakan grafik plot antar nilai prediksi variabel terikat (dependen) yaitu ZPRED dengan residualnya SRESID. Berikut hasil pengujian heteroskedastisitas pada Gambar 1.

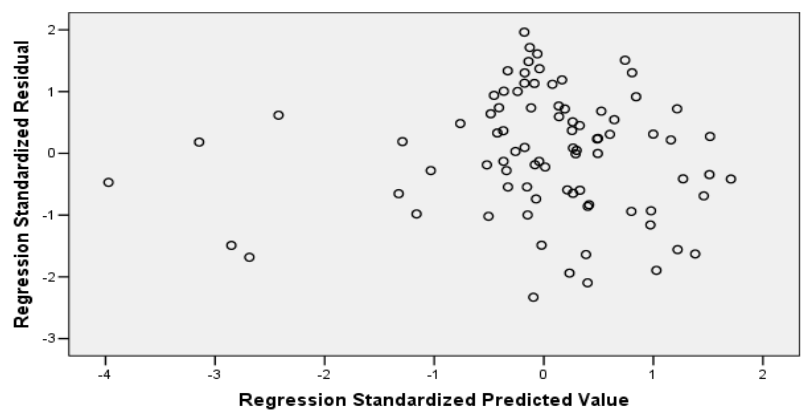

Gambar 1. Pengujian Heterokedestisitas

Dari gambar 1 terlihat bahwa titik-titik menyebar secara acak, tidak membentuk suatu pola. Serta titiktitik menyebar baik diatas maupun dibawah angka nol pada sumbu Y. Hal ini dapat disimpulkan bahwa tidak terjadi heterokedastisitas pada model regresi tersebut, sehingga model regresi layak dipakai untuk analisa berikutnya.

\section{Uji Multikolinieritas}

Salah satu cara untuk menguji multikolinieritas adalah dengan melihat nilai tolerance dan variance inflation factor (VIF). Dalam Ghozali (2016) dikatakan bahwa nilai cut-off yang umum dipakai untuk menunjukkan adanya multikolonieritas adalah nilai tolerance $<0.10$ atau sama dengan nilai
VIF >10. Hasil pengujian multikolinieritas sebagai berikut:

Tabel 4. Nilai VIF Uji Multikolinieritas

\begin{tabular}{|l|r|r|}
\hline \multirow{2}{*}{\multicolumn{1}{|c|}{ Model }} & \multicolumn{2}{c|}{ Collinearity Statistics } \\
\cline { 2 - 3 } & Tolerance & \multicolumn{1}{c|}{ VIF } \\
\hline Auditor Judgement $\left(\mathbf{X}_{\mathbf{2}}\right)$ & 0,328 & 3,051 \\
\hline Etika Profesi $\left(\mathbf{X}_{\mathbf{1}}\right)$ & 0,538 & 1,858 \\
\hline Employee Engagement $\left(\mathbf{X}_{\mathbf{3}}\right)$ & 0,361 & 2,769 \\
\hline
\end{tabular}

Hasil di atas menunjukkan bahwa nilai VIF masingmasing variabel bebas dibawah 10, yakni Auditor Judgement $\left(\mathrm{X}_{1}\right)=3,051$, Etika Profesi $\left(\mathrm{X}_{2}\right)=1,858$, dan Employee Engagement $\left(\mathrm{X}_{3}\right)=2,769$. Berdasarkan hasil tersebut dapat disimpulkan bahwa tidak terdapat multikolinieritas antar variabel bebas dalam model.

\subsection{Estimasi Parameter Regresi Linier Berganda}

Pada penelitian ini, analisis regresi berganda dimaksudkan untuk mengetahui adanya pengaruh antara Auditor Judgement $\left(\mathrm{X}_{1}\right)$, Etika Profesi $\left(\mathrm{X}_{2}\right)$, dan Employee Engagement $\left(\mathrm{X}_{3}\right)$ terhadap Kinerja Auditor (Y). Tujuannya untuk meramalkan atau memperkirakan nilai variabel dependen dalam hubungan sebab-akibat terhadap nilai variabel lain. Dengan menggunakan bantuan aplikasi program SPSS versi 24 , didapat output hasil perhitungan regresi linier berganda sebagai berikut:

Tabel 5. Hasil Perhitungan Nilai Koefisien

\begin{tabular}{|l|c|r|r|c|}
\hline \multirow{2}{*}{\multicolumn{1}{|c|}{ Model }} & \multicolumn{2}{|c|}{$\begin{array}{c}\text { Unstandardized } \\
\text { Coefficients }\end{array}$} & \multirow{2}{*}{ t } & \multirow{2}{*}{ Sig. } \\
\cline { 2 - 3 } & \multicolumn{1}{c|}{ B } & Std. Error & & \\
\hline Constant & 4,675 & 3,776 & 1,238 & 0,219 \\
\hline Auditor Judgement & 0,385 & 0,126 & 3,061 & 0,003 \\
\hline Etika Profesi & 0,608 & 0,122 & 4,993 & 0,000 \\
\hline Employee Engagemen & 0,565 & 0,147 & 0,342 & 0,000 \\
\hline
\end{tabular}

Berdasarkan output di atas didapat nilai kontstanta dan koefisien regresi sehingga dapat dibentuk persamaan regresi linier berganda sebagai berikut:

$Y=4,675+0,385 X_{1}+0,608 X_{2}+0,565 X_{3}$

Persamaan di atas dapat diartikan sebagai berikut:

$\mathrm{a}=4,675 ; \quad$ artinya jika Auditor Judgement $\left(\mathrm{X}_{1}\right)$, Etika Profesi $\left(\mathrm{X}_{2}\right)$, dan Employee Engagement $\left(\mathrm{X}_{3}\right)$ konstan, maka Kinerja Auditor (Y) akan bernilai 4,675 satuan;

$\mathrm{b}_{1}=0,385 ; \quad$ artinya jika Auditor Judgement $\left(\mathrm{X}_{1}\right)$ meningkat sebesar satu satuan dan variabel lainnya konstan, maka 
J Statistika Vol. 12, No. 2, (2019), Hal. 1-8

Kinerja Auditor (Y) akan meningkat sebesar 0,385 satuan;

$\mathrm{b}_{2}=0,608$; artinya jika Etika Profesi $\left(\mathrm{X}_{2}\right)$ meningkat sebesar satu satuan dan variabel lainnya konstan, maka Kinerja Auditor (Y) akan meningkat sebesar 0,608 satuan;

$\mathrm{b}_{3}=0,565 ; \quad$ artinya jika Employee Engagement $\left(\mathrm{X}_{3}\right)$ meningkat sebesar satu satuan dan variabel lainnya konstan, maka Kinerja Auditor (Y) akan meningkat sebesar 0,565 satuan.

\subsection{Analisis Koefisien Determinasi}

Analisis koefisien determinasi digunakan untuk melihat seberapa besar pengaruh variable independen terhadap variable dependen. Hasil pengujian koefisien determinasi sebagai berikut:

$$
\begin{aligned}
\mathrm{KD} & =\mathrm{R}^{2} \times 100 \% \\
& =(0,879)^{2} \times 100 \% \\
& =77,3 \%
\end{aligned}
$$

Tabel 6. Analisis Koefisien Determinasi

\begin{tabular}{|l|c|r|r|r|}
\hline Model & R & $\begin{array}{c}\text { R- } \\
\text { Square }\end{array}$ & $\begin{array}{c}\text { Adjusted } \\
\text { R Square }\end{array}$ & $\begin{array}{c}\text { Std. Error of } \\
\text { the Estimate }\end{array}$ \\
\hline 1 & 0,879 & 0,773 & 0,764 & 5,110 \\
\hline
\end{tabular}

Dengan demikian, maka diperoleh nilai koefisien determinasi sebesar 77,3\% yang menunjukkan arti Auditor Judgement $\left(\mathrm{X}_{1}\right)$, Etika Profesi $\left(\mathrm{X}_{2}\right)$, dan Employee Engagement $\left(\mathrm{X}_{3}\right)$ memberikan pengaruh simultan (bersama-sama) sebesar 77,3\% terhadap Kinerja Auditor (Y), sedangkan sisanya sebesar $22,7 \%$ dipengaruhi oleh faktor lain yang tidak diamati di dalam penelitian ini.

\subsection{Pengujian Hipotesis}

\section{a. Uji Simultan (Uji F)}

Pengujian hipotesis secara simultan adalah suatu pengujian hipotesis yang bertujuan untuk mengetahui apakah secara bersama-sama atau simultan variabel bebas (independen) berpengaruh signifikan atau tidak berpengaruh signifikan terhadap variabel terikat. Hasil pengujian hipotesis secara simultan, sebagai berikut :

Tabel 7. Pengujian Hipotesis Simultan (Uji-F)

\begin{tabular}{|l|c|r|r|r|c|}
\hline \multicolumn{1}{|c|}{ Model } & $\begin{array}{c}\text { Sum of } \\
\text { Square }\end{array}$ & df & $\begin{array}{c}\text { Mean } \\
\text { Square }\end{array}$ & F & Sig. \\
\hline Regression & 7103,43 & 3 & 2367,8 & 90,677 & 0,000 \\
\hline Residual & 2089,01 & 80 & 26,113 & & \\
\hline Total & 9192,43 & 83 & & & \\
\hline
\end{tabular}

Berdasarkan output pada Tabel 7 diketahui nilai $F_{\text {hitung }}$ sebesar 90,677 dengan p-value (sig) 0,000. www.unipasby.ac.id

Dikarenakan nilai $p$-value $<\alpha(0,000<0,05)$ maka $\mathrm{H}_{0}$ ditolak, artinya Auditor Judgement, Etika Profesi, dan Employee Engagement secara bersamasama berpengaruh signifikan terhadap Kinerja Auditor.

\section{b. Uji Persial (Uji t)}

Pengujian hipotesis secara simultan adalah suatu pengujian hipotesis yang bertujuan untuk mengetahui apakah secara persial variabel bebas (independen) berpengaruh signifikan atau tidak berpengaruh signifikan terhadap variabel terikat (dependen). Hasil perhitungan pengujian parsial adalah sebagai berikut :

Tabel 8. Pengujian Hipotesis Parsial (Uji-t)

\begin{tabular}{|l|c|c|c|c|}
\hline \multirow{2}{*}{ Model } & \multicolumn{2}{|c|}{$\begin{array}{c}\text { Unstandardized } \\
\text { Coefficients }\end{array}$} & \multirow{2}{*}{ t } & \multirow{2}{*}{ Sig. } \\
\cline { 2 - 3 } & B & $\begin{array}{c}\text { Std. } \\
\text { Error }\end{array}$ & & \\
\hline Constant & 4,675 & 3,776 & 1,238 & 0,219 \\
\hline Auditor Judgement & 0,385 & 0,126 & 3,061 & 0,003 \\
\hline Etika Profesi & 0,608 & 0,122 & 4,993 & 0,000 \\
\hline $\begin{array}{l}\text { Employee } \\
\text { Engagemen }\end{array}$ & 0,565 & 0,147 & 0,342 & 0,000 \\
\hline
\end{tabular}

1. Dari perhitungan diatas diperoleh nilai $p$-value untuk variabel Auditor Judgement sebesar 0,003 . Dikarenakan $p$-value $<\alpha$ atau $0,003<$ 0,05 , maka $\mathrm{H}_{0}$ ditolak dan $\mathrm{H}_{1}$ diterima. Dimana $\mathrm{H}_{1}$ adalah auditor judgement berpengaruh signifikan terhadap kinerja auditor dalam pelaksanaan pemeriksaan laporan keuangan. Dapat diartikan bahwa Auditor Judgement berpengaruh signifikan terhadap Kinerja Auditor.

2. Dari perhitungan diatas diperoleh nilai $p$-value untuk variabel Etika Profesi sebesar 0,000. Dikarenakan $p$-value $<\alpha$ atau $0,000<0,05$, maka $\mathrm{H}_{0}$ ditolak dan $\mathrm{H}_{1}$ diterima. Dimana $\mathrm{H}_{2}$ adalah etika profesi berpengaruh signifikan terhadap kinerja auditor dalam pelaksanaan pemeriksaan laporan keuangan. Sehingga dapat diartikan bahwa Etika Profesi berpengaruh signifikan terhadap Kinerja Auditor.

3. Dari perhitungan diatas diperoleh nilai $p$-value untuk variabel Employee Engagement sebesar 0,000 . Dikarenakan $p$-value $<\alpha$ atau $0,000<$ 0,05 , maka $\mathrm{H}_{0}$ ditolak dan $\mathrm{H}_{1}$ diterima, artinya Employee Engagement berpengaruh signifikan terhadap Kinerja Auditor. Dimana $\mathrm{H}_{3}$ adalah employee engagement berpengaruh signifikan 
J Statistika Vol. 12, No. 2, (2019), Hal. 1-8

terhadap kinerja auditor dalam pelaksanaan pemeriksaan laporan keuangan.

\section{KESIMPULAN DAN SARAN}

Hasil penelitian ini menunjukkan bahwa Auditor Judgement, Etika Profesi, dan Employee Engagement secara bersama-sama berpengaruh signifikan terhadap Kinerja Auditor. Hal ini menunjukkan bahwa kinerja auditor yang baik akan terbentuk jika Auditor Judgement, Etika Profesi, dan Employee Engagement dilakukan dengan baik. Variabel paling dominan yang membentuk kinerja auditor adalah etika profesi, sedangkan yang paling rendah adalah Auditor Judgement sehingga diperlukan adanya perbaikan terkait dengan Auditor Judgement supaya kinerja auditor dalam pelaksanaan pemeriksaan laporan keuangan lebih baik lagi.

\section{DAFTAR PUSTAKA}

Arens, A. Alvin, Randal J. Elder, dan Mark S. Beasley. 2014. Auditing and Assurance Services: An Integrated Approach, $13^{\text {th }}$ Edition, Pearson Prentice Hall.

Ariani Wahyuningsih, A.A. Ayu. 2009. Pengaruh Profesionalisme, Etika Profesi, Tingkat Pendidikan dan Pengalaman Kerja pada Kinerja Auditor Inspektorat Provinsi Bali. Tesis. Fakultas Ekonomi Universitas Udayana.

Ariyanto, Dodik dan Ardani M.J. 2010. Pengaruh Independensi, Kompetensi, Dan Sensitivitas Etika Profesi Terhadap Produktivitas Kerja Auditor Eksternal (Studi Kasus Pada Auditor Perwakilan BPK RI Provinsi Bali). Jurnal Akuntansi dan Bisnis FEB Udayana. Vol 5 (2), 157168.

Bougie, dan Sekaran. 2013. Edisi 5, Research Methods for Business: A skill Building Approach. New York: John wiley@Sons.

Gabritha Floretta. 2014. Pengaruh Kecerdasan Emosional, Kecerdasan Spiritual, dan Etika Profesi Terhadap Kinerja Auditor Pada Kantor Akuntan Publik di Jakarta. Jurnal. Universitas Binus. Jakarta.

Ghozali, I. Dan Chariri. 2016. Aplikasi Analisis Multivariete Dengan Program IBM SPSS 23 (Edisi 8). Cetakan ke VIII. Semarang: Badan Penerbit Universitas Diponegoro.

Hogarth. R. M., dan H.J. Einhorn. 1992. Order Effects in Belief Updatang: The Belief www.unipasby.ac.id

Adjustment Mode, Cognitive Psychology. 2(4), 1-55.

Jamilah, S, Fanani, Z \& Chandrarin, G. 2007. Pengaruh Gender, Tekanan Ketaatan, dan Kompleksitas Tugas Terhadap Audit Judgement. Proceeding Simposium Nasional Akuntansi X Universitas Hasanudin Makasar. AUEP-06.

Kahn, W.A. 1990. Psychological conditions of personal engagement and disengagement of work. Academy of Management Journal, 33 (4), 692-724.

Khairani, Rina. 2014. Pengaruh Konflik PekerjaanKeluarga pada Intensi Keluar dengan Burout dan Dukungan Atasan Langsung sebagai Pemediasi dan Pemoderasi Studi pada Pemeriksa BPK RI. Tesis. Studi Magister Manajemen. Fakultas Ekonomika dan Bisnis, Universitas Gajah Mada.

Kompas.com.2017.https://nasional.kompas.com/re $\mathrm{ad} / 2017 / 05 / 27 / 14054551 /$ icw.sejak.2005.a da.6.kasus.suap.libatkan.23.pejabat.bpk (diakses 20 Oktober 2017).

Kurnia, Winda. Khomsiyah. Sofie. 2014. "Pengaruh kompetensi, independensi, tekanan waktu, dan etika auditor terhadap kualitas audit". E-Journal Akuntansi Fakultas Ekonomi, Volume. 1 Nomor. 2 September 2014. Hal. 49-67.

Locke, E. A. And Latham, G. P. 1990. A Theory of Goal Setting and Task Performance. Englewood Cliffs, NJ: Pretince-Hall.

Peraturan BPK RI No. 03 Tahun 2016 Tentang Kode Etik BPK. Jakarta: Badan Pemeriksa Keuangan.

Rich, B. Louis. 2010. Job Engagement Antecedents and Effects On Job Performance. Academy of Management Journal. Vol. 53, No. 3, 617-635.

Siegel, Gary \& Marconi, H. Ramanauskas. 1989. Behavioral Accounting. Cincinnati, Ohio: South-Western Publishing Co.

SPKN (Standar Pemeriksaan Keuangan Negara). Peraturan BPK RI No. 01 Tahun 2017. Ditama Binbangkum BPK RI.

Sugiyono. 2016. Metode Penelitian Kuantitatif Kualitataif dan Kombinasi (Mixed Methods). Bandung: Alfabeta.

Susetyo, Budi. 2009. Pengaruh Pengalaman Audit Terhadap Pertimbangan Auditor Dengan Kredibilitas Klien Sebagai Variabel Moderating. Tesis, Magister Sains 
J Statistika Vol. 12, No. 2, (2019), Hal. 1-8

www.unipasby.ac.id

Akuntansi Universitas Diponegoro

Semarang. 